TRAVELS IN THE INTERIOR DISTRICTS OF AFRICA 


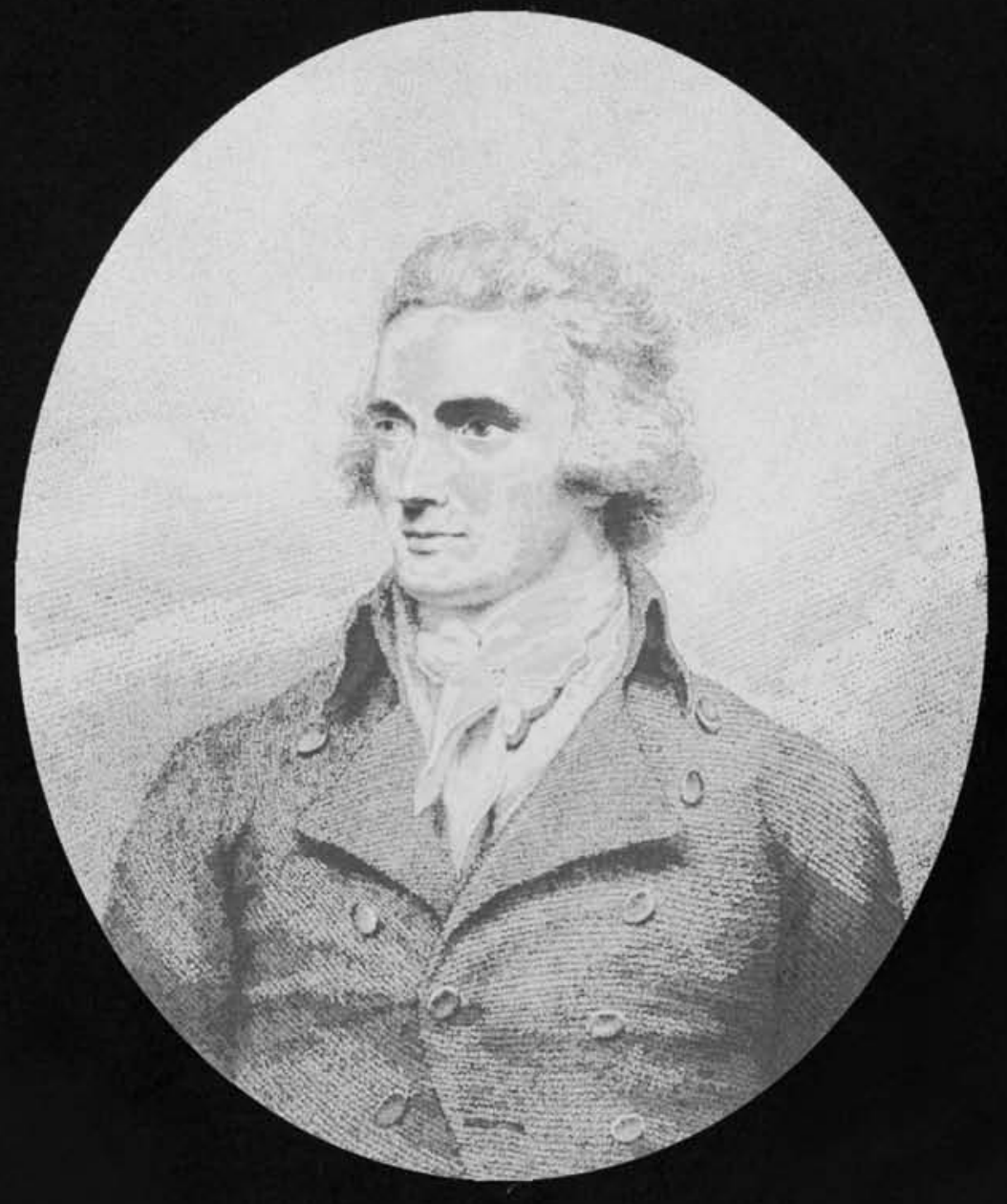

Mungo Park 


\title{
Travels IN THE
}

\section{Interior Districts of Africa}

\author{
by MUNGO PARK
}

Edited with an Introduction by

Kate Ferguson Marsters

Duke University Press Durham and London, 2000 
(ㄷ) 2000 Duke University Press

All rights reserved

Printed in the

United States of America

on acid-free paper @

Typeset in Baskerville by

Tseng Information Systems, Inc.

Library of Congress

Cataloging-in-Publication Data

appear on the last printed page

of this book. 